CLINICAL STUDY

\title{
Muscle inflammatory signaling in response to 9 days of physical inactivity in young men with low compared with normal birth weight
}

\author{
Martin Friedrichsen ${ }^{1,2,3}$, Rasmus Ribel-Madsen ${ }^{1}$, Brynjulf Mortensen ${ }^{1}$, Christina N Hansen ${ }^{2,4}$, Amra C Alibegovic ${ }^{1}$, \\ Lise Højbjerre $^{2,4}$, Mette P Sonne ${ }^{2,4}$, Jørgen F P Wojtaszewski ${ }^{3}$, Bente Stallknecht ${ }^{2}$, Flemming Dela ${ }^{2,4}$ and \\ Allan Vaag ${ }^{1,5}$ \\ ${ }^{1}$ Steno Diabetes Center, Gentofte, Denmark, ${ }^{2}$ Department of Biomedical Sciences, University of Copenhagen, Copenhagen, Denmark, ${ }^{3}$ Molecular Physiology \\ Group, Department of Exercise and Sport Sciences, The August Krogh Centre, University of Copenhagen, Universitetsparken 13, DK-2100 Copenhagen, \\ Denmark, ${ }^{4}$ Center for Healthy Ageing, University of Copenhagen, Copenhagen, Denmark and ${ }^{5}$ Rigshospitalet, Department of Diabetes and Metabolism, \\ Copenhagen, Denmark \\ (Correspondence should be addressed to M Friedrichsen at Molecular Physiology Group, Department of Exercise and Sport Sciences, University of \\ Copenhagen; Email: martin.friedrichsen@ifi.ku.dk)
}

\begin{abstract}
Objective: The molecular mechanisms linking physical inactivity and muscle insulin resistance in humans have been suggested to include increased muscle inflammation, possibly associated with impaired oxidative metabolism. We employed a human bed rest study including 20 young males with normal birth weight (NBW) and 20 with low birth weight (LBW) and increased risk of diabetes.

Methodology: The subjects were studied before and after 9 days of bed rest using the euglycemichyperinsulinemic clamp and muscle biopsy excision. Muscle inflammatory status was assessed as nuclear factor- $\kappa \mathrm{B}(\mathrm{NF}-\kappa \mathrm{B})$ activity and mRNA expression of the pro-inflammatory MCP1 (CCL2) and IL6 and the macrophage marker CD68. Furthermore, mRNA expression of genes central to oxidative phosphorylation (OXPHOS) was measured including ATP5O, COX7A1, NDUFB6, and UQCRB.

Results: At baseline, muscle inflammatory status was similar in NBW and LBW individuals. After bed rest, CD68 expression was increased in LBW $(P=0.03)$ but not in NBW individuals. Furthermore, expression levels of all OXPHOS genes were reduced after bed rest in LBW $(P \leq 0.05)$ but not in NBW subjects and were negatively correlated with $C D 68$ expression in LBW subjects $(P \leq 0.03$ for all correlations). MCP1 expression and NF- $\mathrm{BB}$ activity were unaffected by bed rest, and IL6 expression was too low for accurate measurements. None of the inflammatory markers correlated with insulin sensitivity.

Conclusions: Although LBW subjects exhibit disproportionately elevated CD68 mRNA expression suggesting macrophage infiltration and reduced OXPHOS gene expression when exposed to bed rest, our data altogether do not support the notion that bed rest-induced ( 9 days) insulin resistance is caused by increased muscle inflammation.
\end{abstract}

European Journal of Endocrinology 167 829-838

\section{Introduction}

Insulin resistance is a major component of type 2 diabetes (T2D) (1). Apart from a well-documented genetic influence $(2,3)$, insulin sensitivity is largely determined by age (4), sex (5), body composition/ adiposity (6), and physical activity level (7). In addition, an adverse intra-uterine environment, as evidenced by low birth weight (LBW), has consistently been associated with altered metabolic function in studies of both young and old individuals $(8,9,10,11)$. The prevalence of T2D has increased rapidly over the last decades (12). This has, to a great extent, been attributed to an increasingly sedentary lifestyle (13, 14, 15). Muscle insulin resistance may represent a key mechanism linking physical inactivity with increased risk of developing T2D and may, to some extent, involve increased inflammation $(13,16,17)$. Indeed, several studies have demonstrated that increased insulin sensitivity following exercise training was related to decreased muscle and/or systemic inflammation $(18,19)$. Thus, increased physical activity might, at least in part, increase insulin sensitivity by lowering the level of muscle inflammation. Although studies examining the association between physical activity, insulin resistance, and inflammation are very important from an intervention perspective, most present societies become increasingly sedentary. Thus, a more relevant 
approach is to focus on identifying molecular mechanisms related to physical inactivity as opposed to exercise training in the investigation of T2D pathophysiology. Although cross-sectional studies suggest that physical inactivity and low-grade systemic inflammation are linked (reviewed in Petersen \& Pedersen (20) and Hamer (21)), the effect of physical inactivity on muscle inflammatory status has not previously been studied longitudinally in humans.

The notion of a general link between inflammation and insulin resistance is supported by studies demonstrating that reducing the level of inflammation (e.g. by pharmacological agents) in insulin-resistant humans is an effective treatment of insulin resistance $(22,23)$. Although not supported by all observations $(24,25)$, several studies have implicated activity of the inflammatory inhibitor $\kappa \mathrm{B}$ kinase (IKK)/nuclear factor- $\kappa \mathrm{B}$ $(\mathrm{NF}-\kappa \mathrm{B})$ pathway in skeletal muscle in the pathogenesis of insulin resistance $(18,26,27,28,29)$. The transcription factor $\mathrm{NF}-\kappa \mathrm{B}$ induces expression of pro-inflammatory genes, including tumor necrosis factor- $\alpha(\mathrm{TNF}-\alpha)$, interleukin-6 (IL6), and monocyte chemotactic protein-1 (MCP1 (CCL2)) as well as the TNF- $\alpha$ receptor $(30,31)$. Although the effect of acute IL6 stimulation is still debated, it has been established that chronically elevated plasma levels of TNF- $\alpha$ and IL6 are associated with insulin resistance (16). MCP1 is not only involved in the recruitment of macrophages (32) but may also induce insulin resistance in myocytes directly $(33,34)$. Infiltration of inflammatory cells, including macrophages, directly into the inflamed muscle tissue or in the adipose tissue surrounding the muscle fibers has been demonstrated previously $(35,36,37,38)$. These cells are thought to maintain the inflammatory state and may also represent a source of cytokines acting in a paracrine and/or endocrine manner (35).

In this study, we investigated the effect of 9 days of physical inactivity and subsequent retraining on inflammatory status (NF- $\kappa \mathrm{B}$ activity and mRNA expression of MCP1, IL6, and cluster of differentiation 68 (CD68), a macrophage marker) as well as a set of associated nuclear-encoded OXPHOS genes in skeletal muscle from healthy young males with normal birth weight (NBW) or LBW. We evaluated whether the degree of muscle inflammation after bed rest was associated with the previously described insulin resistance induced by physical inactivity in this study population (39).

\section{Materials and methods}

The data presented in this study are part of a larger study on the influence of physical inactivity in healthy study participants with or without a predisposition to T2D including both LBW subjects and first-degree relatives (FDR) of patients with T2D. Data from this study have been published previously $(17,39,40,41)$. The current study was performed on muscle biopsies obtained during the bed rest studies, and the number of subjects in the individual groups represents the subjects in whom the biopsy tissue amount was sufficient to perform the analyses of inflammatory markers. Due to limited amounts of muscle tissue in the FDR group, our wish to avoid reduced statistical power including more than two groups as well as our prime focus on LBW subjects, measurements of inflammatory markers in FDR muscle biopsies were not performed. This work was initiated and funded by the European Union Framework VI EXGENESIS project.

\section{Participants}

Forty healthy young Caucasian men were recruited via the Danish National Birth Registry according to birth weight (Table 1), as described previously (40). Twenty had LBW (birth weight $<10$ th percentile) and 20 were age-matched controls with NBW (50th percentile $<$ birth weight $<75$ th percentile). All men were singletons born at term in the Copenhagen area, had no family history of diabetes, and had a BMI $<30$.

Table 1 Clinical characteristics. Mean \pm s.D. $M$-value was expressed as $\mathrm{mg}$ glucose/kg FFM per min.

\begin{tabular}{|c|c|c|c|c|}
\hline & \multicolumn{2}{|c|}{ NBW } & \multicolumn{2}{|c|}{ LBW } \\
\hline & Baseline & After bed rest & Baseline & After bed rest \\
\hline$n$ & 20 & 20 & 20 & 20 \\
\hline Birth weight (g) & $3.8 \pm 0.2$ & NA & $2.5 \pm 0.2^{*}$ & NA \\
\hline Age (years) & $25 \pm 1$ & NA & $26 \pm 2$ & NA \\
\hline Height $(\mathrm{cm})$ & $185 \pm 5$ & NA & $179 \pm 5^{\star}$ & NA \\
\hline Weight (kg) & $82.5 \pm 10.1$ & $82.2 \pm 10.4$ & $75.4 \pm 11.1^{*}$ & $75.4 \pm 11.1$ \\
\hline Waist-to-hip ratio & $0.85 \pm 0.04$ & $0.86 \pm 0.04$ & $0.86 \pm 0.06$ & $0.86 \pm 0.07$ \\
\hline BMI $\left(\mathrm{kg} / \mathrm{m}^{2}\right)$ & $24.1 \pm 2.3$ & $23.9 \pm 2.4$ & $23.3 \pm 3.2$ & $23.5 \pm 3.1$ \\
\hline Total fat percentage (\%) & $17.7 \pm 7.3$ & $18.5 \pm 8.1$ & $20.0 \pm 6.9$ & $20.0 \pm 7.4$ \\
\hline Total fat mass $(\mathrm{kg})$ & $14.3 \pm 7.8$ & $15.5 \pm 8.7$ & $14.9 \pm 7.3$ & $15.1 \pm 7.9$ \\
\hline Lean body mass (kg) & $63.8 \pm 4.9$ & $64.2 \pm 3.6$ & $57.2 \pm 6.4^{*}$ & $57.4 \pm 5.9^{*}$ \\
\hline $\mathrm{VO}_{2 \max }(\mathrm{ml} / \mathrm{min}$ per $\mathrm{kg})$ & $44.3 \pm 5.6$ & $43.5 \pm 5.2$ & $43.4 \pm 8.3$ & $40.6 \pm 9.2$ \\
\hline$M$-value & $14.4 \pm 1.7$ & $10.7 \pm 2.0^{\dagger}$ & $13.7 \pm 1.8$ & $10.3 \pm 2.2^{\dagger}$ \\
\hline
\end{tabular}

FFM, fat-free mass; LBW, low birth weight; NBW, normal birth weight. ${ }^{\star} P<0.05$ vs NBW. ${ }^{\dagger} P<0.05$ vs before bed rest. 
The study was approved by the regional ethics committee and conducted according to the principles of the Helsinki Declaration. Informed written consent was obtained from all study participants.

\section{Experimental protocol}

For a detailed description of the experimental protocol, please see previous studies $(17,39,40)$. In short, all participants were admitted to the Steno Diabetes Center, Gentofte, Denmark, for 10 days and were not permitted to deviate from a half-recumbent position during this period. Toilet visits, limited to $15 \mathrm{~min} /$ day, were allowed. During bed rest, a standardized diet with adjusted caloric content (to maintain a stable weight during bed rest) was provided to ensure weight stability. After bed rest, all participants completed a 4-week retraining program, as described previously (17).

\section{Clinical examination}

Before and after bed rest, anthropometric measurements including weight, height, and waist and hip circumferences, determination of body composition by dualenergy X-ray absorptiometry scanning, and estimation of maximal aerobic capacity $\left(\mathrm{VO}_{2 \max }\right)$ by bicycle testing were performed, as described previously (39). Insulin sensitivity was examined by a 3-h euglycemic-hyperinsulinemic clamp $\left(80 \mathrm{mU} / \mathrm{m}^{2}\right.$ per $\left.\mathrm{min}\right)$ before and after 9 days of bed rest. Steady state was defined as the last $30 \mathrm{~min}$ of the basal and insulin-stimulated clamp periods. Insulin sensitivity is given as the average glucose infusion rate during steady state ( $M$-value) (40). Skeletal muscle samples were collected in the basal and insulinstimulated states before and after bed rest, but only in the basal state after retraining. The biopsies were excised from the vastus lateralis muscle under local anesthesia (1\% lidocaine) using a Bergstrom needle with suction applied. The samples were immediately frozen in liquid nitrogen and stored at $-80{ }^{\circ} \mathrm{C}$ until further processed.

\section{Preparation of lysate}

Approximately $50 \mathrm{mg}$ of muscle biopsy was freezedried, dissected free of visible fat and connective tissue, and homogenized using Tissuelyser (Qiagen) in ice-cold buffer (1:80, dw:v) containing $50 \mathrm{mM}$ HEPES (pH 7.5), $150 \mathrm{mM} \mathrm{NaCl}, 20 \mathrm{mM}$ Na-pyrophosphate, $20 \mathrm{mM} \quad \beta$-glycerophosphate, $10 \mathrm{mM}$ NaF, $2 \mathrm{mM}$ Na-orthovanadate, $1 \mathrm{mM}$ EDTA, $1 \mathrm{mM}$ EGTA, $1 \%$ nonidet $\mathrm{P}-40,10 \%$ glycerol, $2 \mathrm{mM}$ phenylmethylsulphonyl fluoride, $10 \mu \mathrm{g} / \mathrm{ml}$ leupeptin, $10 \mu \mathrm{g} / \mathrm{ml}$ aprotinin, and $3 \mathrm{mM}$ benzamidine. Homogenates were rotated end-over-end for $1 \mathrm{~h}$ at $4{ }^{\circ} \mathrm{C}$ and cleared by centrifugation at $17500 \boldsymbol{g}$ at $4^{\circ} \mathrm{C}$ for $1 \mathrm{~h}$. The lysate was stored at $-80^{\circ} \mathrm{C}$. Protein content was measured using the bicinchoninic acid assay (Pierce, Rockford, IL, USA).

\section{NF- $\kappa$ B activity}

Basal and insulin-stimulated NF- $\kappa \mathrm{B}$ activities were evaluated as DNA-binding capacity employing an ELISA-based kit (\#40097, Active Motif, Carlsbad, CA, USA). This assay was only run on 127 basal and insulinstimulated samples (68 NBW samples and $59 \mathrm{LBW}$ samples) due to limitations in biopsy availability. Twenty micrograms of protein from whole-tissue lysates were loaded in duplicate, and the assay was performed according to the manufacturer's recommendations. The sample was rerun if the signal between duplicates deviated more than 10\%. Signal intensity was normalized to a standard loaded on all plates.

\section{mRNA expression}

RNA was extracted from $\sim 50 \mathrm{mg}$ skeletal muscle biopsy using TRI reagent (Sigma-Aldrich). cDNA was synthesized using RevertAid first-strand cDNA synthesis kit (Fermentas Life Sciences, Burlington, ON, Canada). Basal CD68 (Hs00154355_m1, average $C_{\mathrm{t}}=30.1$ cycles), CCL2 (MCP1) (HsO0234140_m1, average $C_{\mathrm{t}}=30.0$ cycles), and IL6 (Hs00985639_m1, average $C_{\mathrm{t}}=35.1$ cycles) expression levels were quantified using TaqMan real-time PCR on an ABI Prism 7900 HT platform (Applied Biosystems, Foster City, CA, USA) using the standard curve method (51 NBW samples and $53 \mathrm{LBW}$ samples). The gene expression was normalized to PPIA (cyclophilin A) (4326316E, average $C_{\mathrm{t}}=25.6$ cycles) and expressed in arbitrary units (AU). mRNA expression of cyclophilin A was similar in the birth weight groups and was not significantly affected by bed rest within each group. One data point (CD68 expression after bed rest in a NBW individual) was removed as an outlier, being $>35$ S.D. higher than the average. The mRNA expressions of ATP synthase subunit O (ATP5O (Hs00426889_m1)), cytochrome $c$ oxidase polypeptide 7A1 (COX7A1 (Hs00156989_m1)), NADH dehydrogenase 1 beta subcomplex subunit 6 (NDUFB6 (HsO0159583_m1)), and ubiquinol-cytochrome $c$ reductase binding protein (UQCRB (HsO0559884_ m1)) were measured by low-density arrays (Applied Biosystems) as described previously (17). The relative amount of target mRNA was calculated using the comparative threshold cycle method. Cyclophilin A (PPIA; Hs99999904_m1) was used as the reference gene for normalization.

\section{Statistical analysis}

All statistical tests were performed in SAS (version 9.1, SAS Institute, Cary, NC, USA). Data are presented as mean \pm s.D. $P \leq 0.05$ was considered significant. Repeated measures analyses (using the proc-mixed procedure) were performed to evaluate the effect of bed rest and birth weight as well as the interaction between birth weight and the response to bed rest. In case of significant effects/interactions, post hoc paired 
and unpaired $t$-tests were employed for comparison of dependent and independent observations respectively. Furthermore, $t$-tests were employed to evaluate the effect of training (from baseline measurements). Spearman's rank correlation coefficient was calculated to evaluate the correlation between two continuous variables.

\section{Results}

\section{Clinical characteristics}

Baseline characteristics of the individuals and the physiological effects of bed rest have been described previously $(40,41)$. In brief, LBW participants had lower height and lean body mass but similar insulin sensitivity and adiposity as NBW participants (Table 1). After bed rest, insulin sensitivity was decreased in both groups, and a tendency toward lower $\mathrm{VO}_{2 \max }$ was seen, especially in LBW individuals. Measures of adiposity and body composition were not affected by bed rest.

\section{Skeletal muscle mRNA expression of inflam- matory markers}

CD68 expression was similar in NBW and LBW individuals at baseline $(P=0.34$, Fig. 1$)$. However, we found a differential effect of bed rest on LBW compared with NBW individuals $(P=0.03$ for the interaction) when employing repeated measures analyses. In LBW participants, CD68 expression was increased after bed rest $(P=0.02)$ and was normalized after retraining $(P=0.99$ for the test of difference between before bed rest and after retraining values), whereas CD68 expression was unaffected by both bed rest $(P=0.86)$ and retraining in NBW individuals $(P=0.72)$.

MCP1 expression was similar in NBW and LBW participants at baseline $(P=0.33$, Fig. 1$)$ and did not change significantly in response to bed rest $(P=0.96)$. In support of these results, no interaction was found between bed rest and birth weight $(P=0.69)$ on $M C P 1$ expression. Regardless, increased MCP1 expression was observed after retraining in NBW individuals $(P=0.03)$. IL6 mRNA levels were too low to be measured accurately (data not shown).

\section{NF- $\kappa$ B activity}

We found no effect of birth weight $(P=0.82)$ or bed rest $(P=0.83)$ on NF- $\kappa$ B activity in skeletal muscle (Fig. 1). Additionally, no significant interaction was found between bed rest and birth weight $(P=0.78)$. Similarly, we found no effect of retraining on muscle NF- $\kappa \mathrm{B}$ activity in NBW $(P=0.89)$ or LBW individuals $(P=0.32)$. Finally, insulin stimulation did not affect muscle NF- $\kappa$ B activity before or after bed rest $(P>0.39$ for all paired $t$-tests, Fig. 2).
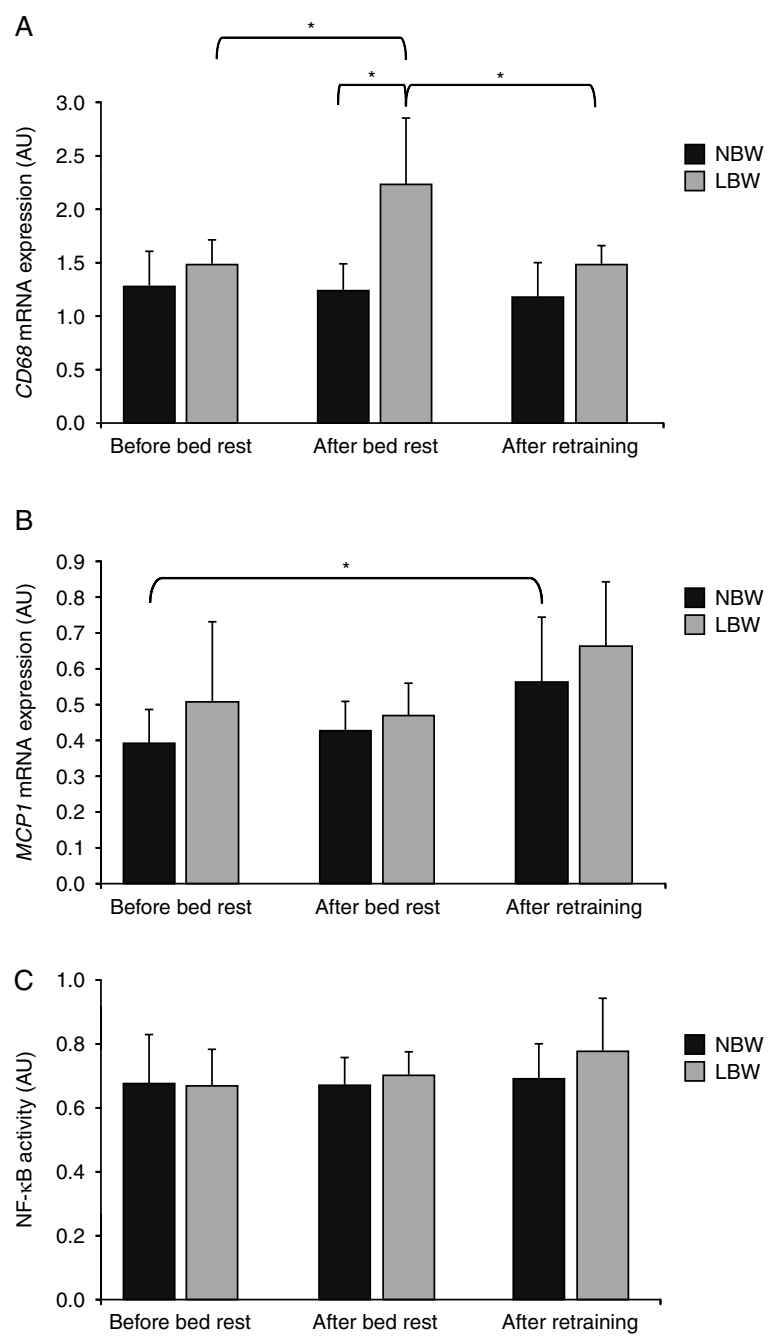

Figure 1 Effect of bed rest on muscle inflammatory status. Basal CD68 (A) and MCP1 (B) mRNA expression as well as basal NF- $\kappa B$ activity (C) were measured before bed rest, after bed rest, and after retraining in NBW and LBW individuals. The mRNA expression was normalized to PPIA (cyclophilin A). Due to the variation in sample numbers, we include the number of samples in each analysis. For CD68 expression (A): before bed rest (BB), 18 NBW and 16 LBW individuals; after bed rest (AB), $17 \mathrm{NBW}$ and $17 \mathrm{LBW}$ individuals; after retraining (AR), nine NBW and $17 \mathrm{LBW}$ individuals. For MCP1 expression (B): BB: 16 NBW and 16 LBW individuals; AB: 16 NBW and 18 LBW individuals; AR: 11 NBW and 15 LBW individuals. For NF- $\kappa$ B activity (C): BB: 14 NBW and nine LBW individuals; AB: 13 NBW and 13 LBW individuals; AR: 11 NBW and 13 LBW individuals. Data are presented as mean \pm 1.96 S.E.M. AU, arbitrary units. ${ }^{\star} P<0.05$.

\section{Correlation analyses for inflammatory mediators}

At baseline, CD68 expression was correlated positively with $\mathrm{BMI}\left(r_{\mathrm{s}}\right.$ (Spearman's rank correlation coefficient $)=0.53$, $P=0.02)$ and fat percentage $\left(r_{\mathrm{s}}=0.56, P=0.01\right)$ and negatively with $\mathrm{VO}_{2 \max }$ in NBW individuals $\left(r_{\mathrm{s}}=-0.56\right.$, $P=0.02)$. In LBW individuals, similar tendencies, although not significant, were seen. No significant correlation was found between CD68 expression and 

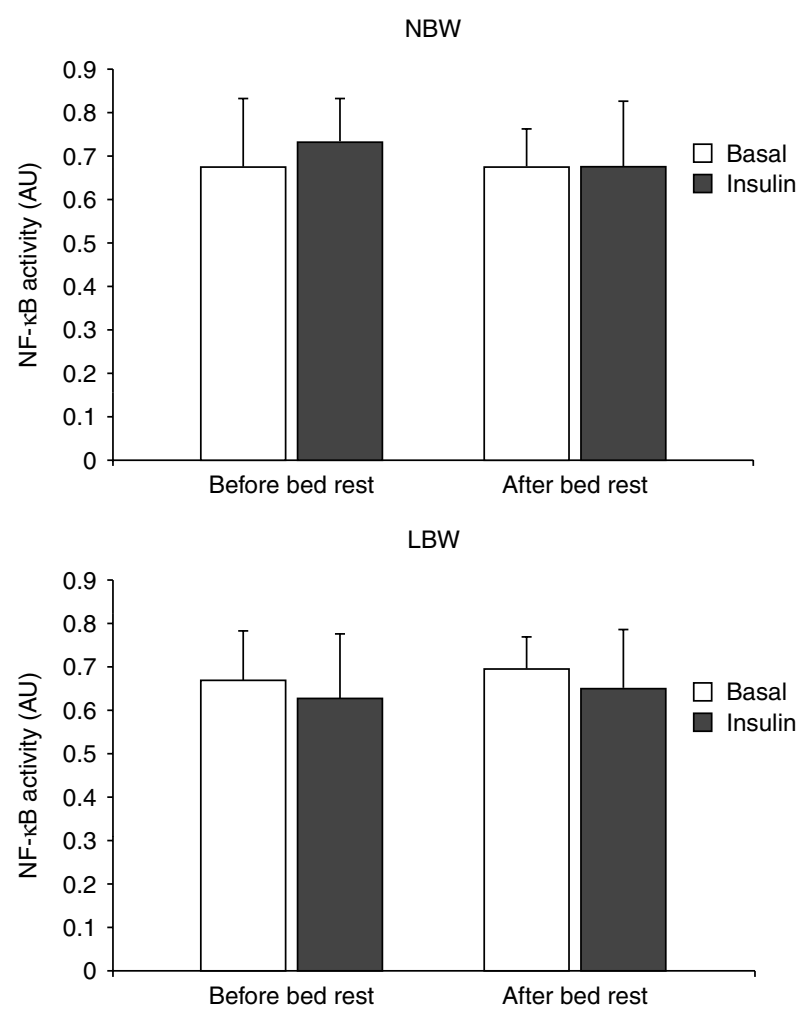

Figure 2 Effect of insulin stimulation on muscle NF-кB activity. Basal and insulin-stimulated NF- $\kappa$ B activity was measured before and after bed rest in NBW and LBW individuals. Due to the variation in sample numbers, we include the number of samples in each analysis. For NBW (A): before bed rest (BB), 14 basal and 14 insulin-stimulated samples; after bed rest (AB), 13 basal and 15 insulin-stimulated samples. For LBW (B): BB: nine basal and 12 insulin-stimulated samples; AB: 13 basal and 12 insulin-stimulated samples. Data are presented as mean \pm 1.96 S.E.M. $\mathrm{AU}$, arbitrary units. ${ }^{*} P<0.05$.

NF- $\kappa B$ activity in NBW or LBW individuals $(P \geq 0.25$ for both analyses). MCP1 expression was not significantly correlated with adiposity or $\mathrm{VO}_{2 \max }$ in NBW or LBW individuals at baseline ( $P \geq 0.23$ for all analyses). In NBW individuals, $M C P 1$ expression was negatively correlated with NF- $\kappa$ B activity $\left(r_{\mathrm{s}}=-0.64, P=0.03\right)$, which was not the case for LBW individuals $\left(r_{\mathrm{s}}=-0.17, P=0.69\right)$. Muscle NF- $\kappa \mathrm{B}$ activity was significantly negatively correlated with fat percentage $\left(r_{\mathrm{s}}=-0.68, P=0.04\right)$ in NBW but not in LBW individuals $\left(r_{\mathrm{s}}=0.08, P<0.83\right)$ at baseline. NF- $\kappa \mathrm{B}$ activity was not significantly associated with BMI or $\mathrm{VO}_{2 \text { max }}$. Muscle inflammatory status as evaluated by the mRNA expression of CD68 and MCP1, as well as NF- $\mathrm{KB}$ activity, was not significantly associated with whole-body insulin sensitivity $(P \geq 0.33$ for all analyses, Fig. 3).

\section{Regulation of oxidative metabolism and its possible link to inflammation}

We have chosen four key genes central to oxidative phosphorylation (OXPHOS) in skeletal muscle $(11,42)$ to illustrate the effect of bed rest on oxidative metabolism: ATP5O, COX7A1, NDUFB6, and UQCRB. The gene expression data (OXPHOS genes) on NBW individuals have been published previously (17) and will thus not be described in detail but only be used as reference points in the analyses of the LBW data. mRNA expression of the OXPHOS genes was significantly reduced after bed rest in LBW individuals (Table 2) whereas OXPHOS gene expression was generally unaffected in NBW individuals (except for NDUFB6, Table 2). To investigate whether the increased CD68 mRNA expression after bed rest in LBW individuals could be associated with the decreased expression of OXPHOS genes in LBW individuals, we performed correlation analyses. At baseline, CD68 expression was negatively correlated with UQCRB expression in LBW subjects $\left(r_{\mathrm{s}}=-0.51, P=0.04\right)$ as well as ATP5O $\left(r_{\mathrm{s}}=-0.48, P=0.04\right)$ and UQCRB $\left(r_{\mathrm{s}}=-0.48\right.$, $P=0.04$ ) expression in NBW. After bed rest, CD68 mRNA expression was negatively correlated with the mRNA expression of all four OXPHOS genes $(P \leq 0.03$ for all analyses) in both LBW and NBW individuals (except for NDUFB6 expression in NBW subjects $\left.\left(r_{\mathrm{s}}=-0.43, P=0.09\right)\right)$. At baseline, NF- $\mathrm{KB}$ activity and MCP1 mRNA expression were not significantly correlated with the mRNA expression of any of the four OXPHOS genes in either LBW or NBW individuals ( $P>0.40$ for all analyses).

\section{Discussion}

In this study, we found a differential response in LBW compared with NBW individuals to the diabetogenic challenge of bed rest: muscle CD68 mRNA expression was increased, and mRNA expression of all four OXPHOS genes measured was decreased after bed rest in LBW but not in NBW individuals. Moreover, CD68 mRNA expression was negatively correlated with expression of the four OXPHOS genes after bed rest. We found no effect of bed rest on muscle MCP1 expression or on NF- $\kappa \mathrm{B}$ activity. Muscle inflammatory status as estimated by NF- $\kappa \mathrm{B}$ activity and mRNA expression of CD68 or MCP1 was not associated with insulin sensitivity in either NBW or LBW individuals.

Most studies investigating the link between insulin sensitivity, physical activity level, and inflammation have employed increased physical activity as the intervention $(18,19)$. However, in most societies, the general - and rather unfortunate - development is not an increased physical activity level but rather a trend to reduce it. Furthermore, even if exercise training increases insulin sensitivity through lowered muscle inflammation in a direct causal manner, as some studies indicate $(18,19)$, this does not necessarily entail that the mechanism for the reverse scenario with physical inactivity-induced insulin resistance develops in the exact opposite causal manner. In this study, 

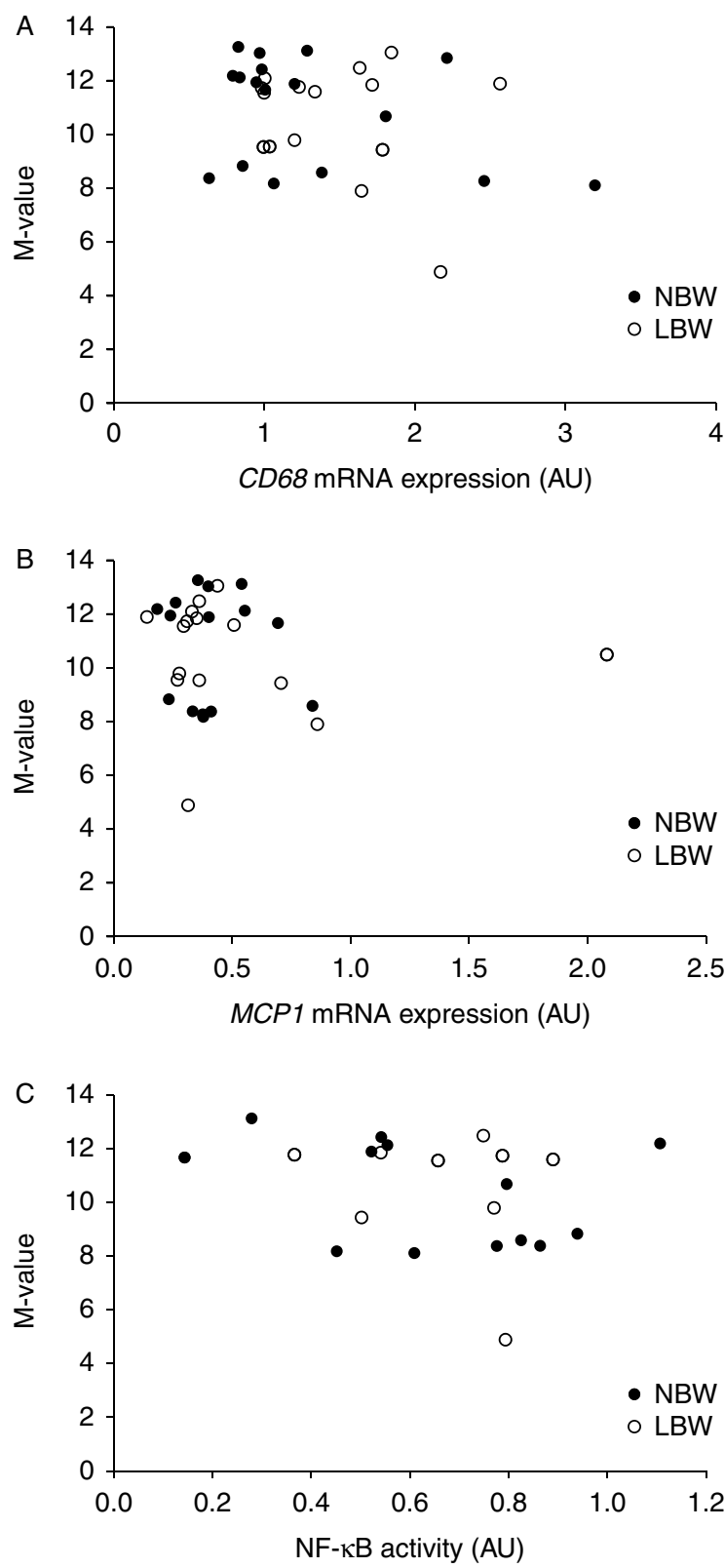

Figure 3 Association between $M$-value (insulin sensitivity) and muscle inflammatory status. Scatter plots of $M$-value as a function of CD68 mRNA expression (A), MCP1 mRNA expression (B), and NF- $\kappa B$ activity $(C)$. The mRNA expression was normalized to PPIA (cyclophilin A). Muscle inflammatory status as evaluated by the mRNA expression of $C D 68$ and $M C P 1$ as well as NF-KB activity was not significantly correlated with $M$-value in LBW or NBW subjects ( $P \geq 0.33$ for all analyses).

we addressed aspects of the molecular mechanisms underlying the association between physical inactivity and risk of developing T2D. It might be argued that complete inactivity is inappropriate to reflect the relative physical inactivity seen in most individuals developing T2D. However, the applied bed rest challenge in a real world setting may be comparable with periods of hospitalization or with the periods of inactivity experienced on a daily basis in long-distance truck drivers.

CD68, a glycoprotein primarily expressed by macrophages, has previously been used as a marker of macrophage infiltration $(35,43,44)$. It may be argued that elevated CD68 mRNA expression may not necessarily imply an increased number of macrophages. Nonetheless, a recent study demonstrated that CD68 mRNA expression correlated with the number of CD68-positive cells evaluated by immunohistochemistry (43). However, CD68 is also, to some extent, expressed by other cell types including fibroblasts (45). Altogether, we recognize that CD68 mRNA expression represents a very rough estimate of the degree of macrophage infiltration. A more direct approach includes immunohistochemical staining of CD68 protein in the tissue, which should be employed in future studies aiming at validating the results obtained in this study. Unfortunately, this was not possible in the current study due to limitations in biopsy availability. In this study, we demonstrated a differential response between NBW and LBW subjects to bed rest to which only LBW individuals responded with increased CD68 expression. This suggests that an adverse intrauterine environment might predispose to increased macrophage infiltration in response to the stress induced by physical inactivity. Regardless, we found no evidence that such macrophage infiltration (CD68 mRNA expression) influenced either muscle insulin action or inflammatory signaling through NF- $\mathrm{KB}$ in LBW or NBW individuals. Thus, the possibilities remain that i) macrophage infiltration in LBW subjects may reflect a secondary and nondisease-causing effect and ii) increased inflammation may confer risk of T2D due to influences in nonmuscle tissues including liver or fat in LBW subjects. Furthermore, it can be speculated that an adverse effect of increased muscle inflammation (macrophage infiltration estimated from CD68 mRNA expression) in LBW individuals may occur only after prolonged tissue exposure. Regardless, increased muscle inflammatory signaling cannot explain the severe in vivo insulin resistance already seen after 9 days.

The differential responses of muscle OXPHOS and CD68 gene expression in LBW individuals after bed rest does to some extent support the idea of LBW individuals being more sensitive to the adverse metabolic effects of physical inactivity compared with the NBW controls. However, our data do not indicate that these differences translated into disproportionally adverse effects on whole-body insulin action in the LBW subjects who were as insulin resistant as the NBW controls after 9 days of bed rest. We of course cannot exclude that LBW subjects were more insulin resistant in the tissue of skeletal muscle (as opposed to whole-body metabolism) after bed rest or that whole-body insulin resistance in the LBW subjects could have been documented if other in vivo insulin action measurement methods were used. Indeed, we have previously demonstrated that young 
Table 2 Impact of bed rest on key genes involved in oxidative metabolism in skeletal muscle. Mean \pm S.E.M. Data on OXPHOS gene expression in NBW individuals have been published previously (17) and will therefore only be used as reference points in the analyses of the LBW data. The mRNA expression was normalized to PPIA (cyclophilin A).

\begin{tabular}{|c|c|c|c|c|}
\hline mRNA expression & Before bed rest & After bed rest & Retraining & $\boldsymbol{P}$ (bed rest effect) \\
\hline \multicolumn{5}{|l|}{ NBW $(n=20)$} \\
\hline ATP5O (AU) & $0.95 \pm 0.09$ & $0.68 \pm 0.09$ & $0.71 \pm 0.06$ & 0.08 \\
\hline COX7A1 (AU) & $1.18 \pm 0.10$ & $0.97 \pm 0.12$ & $0.90 \pm 0.12$ & 0.21 \\
\hline NDUFB6 (AU) & $1.12 \pm 0.12$ & $0.74 \pm 0.09$ & $0.88 \pm 0.08$ & 0.03 \\
\hline UQCRB (AU) & $1.02 \pm 0.09$ & $0.79 \pm 0.09$ & $0.76 \pm 0.07$ & 0.11 \\
\hline \multicolumn{5}{|l|}{ LBW $(n=16)$} \\
\hline ATP5O (AU) & $0.96 \pm 0.08$ & $0.54 \pm 0.07$ & $0.78 \pm 0.08$ & 0.0008 \\
\hline COX7A1 (AU) & $1.51 \pm 0.14$ & $1.08 \pm 0.19$ & $1.21 \pm 0.18$ & 0.05 \\
\hline NDUFB6 (AU) & $1.16 \pm 0.10$ & $0.73 \pm 0.09$ & $0.94 \pm 0.08$ & 0.0015 \\
\hline UQCRB (AU) & $1.08 \pm 0.09$ & $0.69 \pm 0.10$ & $0.87 \pm 0.08$ & 0.003 \\
\hline
\end{tabular}

The $P$ values were calculated from paired $t$-tests using pre- and post-bed rest values. ATP5O, ATP synthase subunit O; COX7A1, cytochrome $c$ oxidase polypeptide 7A1; NDUFB6, NADH dehydrogenase 1 beta subcomplex subunit 6; OXPHOS, oxidative phosphorylation; UQCRB, ubiquinol-cytochrome $c$ reductase binding protein.

LBW subjects displayed normal whole-body insulin sensitivity even in the presence of a decreased insulinmediated glucose uptake in the forearm $(41,46)$.

We found a negative association between mRNA expression of CD68 and four OXPHOS genes in LBW individuals after bed rest, suggesting that the decreased OXPHOS expression in LBW subjects might be associated with their increased CD68 mRNA expression. However, our study cannot determine the extent to which these associations were causal. NF- $\kappa$ B activity was not correlated with any of the four OXPHOS genes before or after bed rest in NBW or LBW subjects arguing against a tight association between NF- $\kappa \mathrm{B}$ activity and OXPHOS gene expression in skeletal muscle.

Interestingly, CD68 expression was correlated positively with adiposity and negatively with $\mathrm{VO}_{2 \max }$. However, CD68 expression was not correlated with insulin sensitivity before or after bed rest (data not shown), supporting the view that factors other than inflammation caused the insulin resistance induced by bed rest. The link between obesity and increased macrophage content in adipose tissue is well established $(36,44,47)$. In accordance with Varma et al. (38), our study indicates that obesity is associated with elevated macrophage infiltration (CD68 mRNA expression) in muscle. Furthermore, our data suggest that a high physical fitness level might be linked to decreased macrophage infiltration.

The similar MCP1 mRNA expression in LBW and NBW subjects at baseline corresponded well with the similar CD68 expression and NF- $\mathrm{BB}$ activity, indicating that LBW per se is not associated with increased muscle inflammation in these subjects. As MCP1 expression was not affected by bed rest, our data suggest that the increase in muscle macrophage content in LBW after bed rest occurred by an MCP1-independent mechanism. However, as MCP1 protein content was not measured, we cannot exclude that the increased macrophage infiltration could, at least partly, be a consequence of elevated muscle MCP1 protein levels. Acute exercise in humans and rodents increases muscle MCP1 mRNA expression $(28,48)$. Similarly, we found increased MCP1 expression after retraining in NBW subjects. Whether MCP1 expression is involved in mediating some metabolic effects of exercise in skeletal muscle, including angiogenesis as previously suggested $(28,48)$, needs to be further investigated in human studies. However, our study indicates that the mechanism does not include recruitment of macrophages, as CD68 expression was unaffected by retraining.

Muscle MCP1 gene expression was not associated with adiposity, $\mathrm{VO}_{2 \max }$, or insulin sensitivity. This is in contrast to MCP1 expression in adipose tissue, which is associated positively with BMI and negatively with insulin sensitivity $(43,47,49)$. Our study participants were generally insulin sensitive, so the association between insulin sensitivity and MCP1 expression may not be evident in this population. By contrast, the range in BMI was relatively broad $\left(19-30 \mathrm{~kg} / \mathrm{m}^{2}\right)$, suggesting that muscle MCP1 expression is unaffected by adiposity in normal and over weight individuals, similar to previous findings in lean and obese (28). Altogether, it seems that MCP1 expression in adipose tissue is dependent on body composition (49), whereas it is regulated by other, as yet unidentified, factors in skeletal muscle. Although MCP1 and CD68 mRNA expression is positively correlated with human adipose tissue (47), we found no significant correlation between these inflammatory markers in muscle (data not shown). Future studies should investigate whether MCP1 is as important in the recruitment of macrophages into muscle as it seems to be in adipose tissue.

We found similar muscle NF- $\kappa$ B activity in NBW and LBW individuals, which is in accordance with our previous study (25). No effect of bed rest or retraining was found on muscle NF- $\kappa$ B activity, suggesting that the observed effect of bed rest on insulin sensitivity and CD68 expression and the effect of retraining on MCP1 expression were not mediated by elevated NF- $\mathrm{B}$ activity. The 'lack' of association between physical inactivity and $\mathrm{NF}-\kappa \mathrm{B}$ activity is in line with the dissociation between $\mathrm{VO}_{2 \max }$ and muscle NF- $\kappa \mathrm{B}$ activity 
seen in this and in our previous studies (25). Thus, although training-induced increases in $\mathrm{VO}_{2 \max }$ were

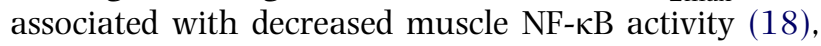
decreased $\mathrm{VO}_{2 \max }$ induced by inactivity did not affect NF- $\kappa \mathrm{B}$ activity. This clearly illustrates the complex relationship between physical activity status and muscle NF- $\kappa \mathrm{B}$ activity, which needs further investigation in intervention studies including both increased and decreased physical activity. We found no positive association between adiposity and muscle NF- $\kappa \mathrm{B}$ activity as suggested by previous studies $(28,50)$. In the most recent of these studies, NF- $\mathrm{BB}$ activity was only positively correlated with one measure of adiposity but not with others (50). In addition, the analyses were not corrected for age and sex (50), which are important determinants of muscle NF- $\mathrm{BB}$ activity (25). In accordance with some $(25,50)$ but not all studies (18), we found no association between baseline muscle NF- $\kappa \mathrm{B}$ activity and insulin sensitivity. This finding supports the notion that NF- $\mathrm{KB}$ activity in muscle may not be involved in the regulation of insulin sensitivity.

In line with previous studies employing 2 or $6 \mathrm{~h}$ of insulin infusion $(25,51)$, we found no effect of $3 \mathrm{~h}$ of supraphysiological insulin stimulation $\left(80 \mathrm{mU} / \mathrm{m}^{2}\right.$ per min) on NF- $\kappa$ B activity. By contrast, high insulin levels have been reported to activate NF- $\mathrm{BB}$ in cell lines $(52,53)$. The transition from cell lines to humans coupled with the very high insulin levels in both cell line studies might explain the discrepancy between the human and cell line studies.

Similar to our results in muscle, we previously demonstrated that 9 days of bed rest did not affect measures of systemic or adipose tissue inflammation in the NBW individuals (54). Interestingly, bed rest was associated with increased plasma TNF- $\alpha$ levels in young healthy FDR (54). Altogether, these studies indicate that persons predisposed to T2D, either genetically or due to an adverse intrauterine environment, might display a stronger inflammatory response (increased macrophage infiltration as estimated by $C D 68$ mRNA expression in LBW individuals and elevated TNF- $\alpha$ levels in FDR) to physical inactivity. This might contribute to their increased prevalence of T2D in sedentary societies.

Although we only found modest effects of bed rest on determinants of muscle inflammation in this study, we cannot exclude effects on other measures of muscle inflammation. We attempted to determine muscle IL6 mRNA expression, but it was too low to be measured accurately. In addition, we performed western blot analyses for protein detection of IL6, MCP1, and TNF- $\alpha$ in skeletal muscle. However, we could not reliably detect the amounts of any of the proteins in this experimental setting including young, nonobese male subjects. Finally, we cannot exclude that increased muscle inflammation might be a trigger for the reduced insulin sensitivity seen in other states of physical inactivity, including chronic adoption to a sedentary lifestyle.
In summary, CD68 mRNA expression was increased after bed rest in LBW but not in NBW individuals, indicating increased muscle macrophage infiltration in LBW subjects, possibly associated with reduced OXPHOS gene expression after bed rest. However, MCP1 expression and NF- $\mathrm{KB}$ activity were unaffected by bed rest in both groups. CD68 and MCP1 expression as well as NF- $\kappa$ B activity were not associated with insulin sensitivity. Altogether, our study indicates that the quantitatively marked 'insulin-desensitizing' effect of short-term bed rest (9 days) in both LBW and NBW subjects (39) is unlikely to be mediated through increased inflammation in skeletal muscle. Thus, the proposed link $(20,21)$ between physical inactivity and low-grade inflammation could not be supported by this study.

\section{Declaration of interest}

The authors declare that there is no conflict of interest that could be perceived as prejudicing the impartiality of the research reported.

\section{Funding}

This study was furthermore supported by grants from The Danish Council for Strategic Research (grant no. 2101-07-0025), The Danish Council for Independent Research, Medical Research (grant no. 10-084648), and The European Union Framework VI EXGENESIS project (grant no. LSHM-CT-2004-005272).

\section{Author contribution statement}

M Friedrichsen, B Mortensen, C N Hansen, A C Alibegovic, L Højbjerre, M P Sonne, and J F P Wojtaszewski researched the data. M Friedrichsen wrote the manuscript. M Friedrichsen, R Ribel-Madsen, B Mortensen, J F P Wojtaszewski, B Stallknecht, F Dela, and A Vaag contributed to discussion. M Friedrichsen, R Ribel-Madsen, B Mortensen, A C Alibegovic, L Højbjerre, M P Sonne, J F P Wojtaszewski, B Stallknecht, F Dela, and A Vaag reviewed and edited the manuscript.

\section{Acknowledgements}

The authors thank all the young men for their participation in this study. Additionally, the technical assistance of Marianne Modest and Lars Sander Koch is gratefully acknowledged. M Friedrichsen was supported by a PhD grant from the Danish Agency for Science Technology and Innovation.

\section{References}

1 Reaven GM. Banting lecture 1988. Role of insulin resistance in human disease. Diabetes 198837 1595-1607. (doi:10.2337/ diabetes.37.12.1595)

2 Mayer EJ, Newman B, Austin MA, Zhang D, Quesenberry CP Jr, Edwards K \& Selby JV. Genetic and environmental influences on insulin levels and the insulin resistance syndrome: an analysis of women twins. American Journal of Epidemiology 1996143 323-332. (doi:10.1093/oxfordjournals.aje.a008746)

3 Poulsen P, Kyvik KO, Vaag A \& Beck-Nielsen H. Heritability of type II (non-insulin-dependent) diabetes mellitus and abnormal glucose tolerance - a population-based twin study. Diabetologia 199942 139-145. (doi:10.1007/s001250051131) 
4 DeFronzo RA. Glucose intolerance and aging. Diabetes Care 19814 493-501. (doi:10.2337/diacare.4.4.493)

5 Yki-Jarvinen H. Sex and insulin sensitivity. Metabolism 198433 1011-1015. (doi:10.1016/0026-0495(84)90229-4)

6 Ferrannini E. Physiological and metabolic consequences of obesity. Metabolism 199544 15-17. (doi:10.1016/0026-0495 (95)90313-5)

7 Soman VR, Koivisto VA, Deibert D, Felig P \& DeFronzo RA. Increased insulin sensitivity and insulin binding to monocytes after physical training. New England Journal of Medicine 1979301 1200-1204. (doi:10.1056/NEJM197911293012203)

8 Jensen CB, Storgaard H, Dela F, Holst JJ, Madsbad S \& Vaag AA. Early differential defects of insulin secretion and action in 19-year-old Caucasian men who had low birth weight. Diabetes 200251 1271-1280. (doi:10.2337/diabetes.51.4.1271)

9 Hales CN, Barker DJ, Clark PM, Cox LJ, Fall C, Osmond C \& Winter PD. Fetal and infant growth and impaired glucose tolerance at age 64. BMJ 1991303 1019-1022. (doi:10.1136/ bmj.303.6809.1019)

10 Poulsen P, Levin K, Beck-Nielsen H \& Vaag A. Age-dependent impact of zygosity and birth weight on insulin secretion and insulin action in twins. Diabetologia 200245 1649-1657. (doi:10.1007/s00125-002-0983-6)

11 Brons C, Jacobsen S, Nilsson E, Ronn T, Jensen CB, Storgaard H, Poulsen P, Groop L, Ling C, Astrup A \& Vaag A. Deoxyribonucleic acid methylation and gene expression of PPARGC1A in human muscle is influenced by high-fat overfeeding in a birth-weightdependent manner. Journal of Clinical Endocrinology and Metabolism 201095 3048-3056. (doi:10.1210/jc.2009-2413)

12 Mokdad AH, Ford ES, Bowman BA, Dietz WH, Vinicor F, Bales VS \& Marks JS. Prevalence of obesity, diabetes, and obesity-related health risk factors, 2001. Journal of the American Medical Association 2003289 76-79. (doi:10.1001/jama.289.1.76)

13 Kolb H \& Mandrup-Poulsen T. The global diabetes epidemic as a consequence of lifestyle-induced low-grade inflammation. Diabetologia 201053 10-20. (doi:10.1007/s00125-009-1573-7)

14 Slentz CA, Houmard JA \& Kraus WE. Exercise, abdominal obesity, skeletal muscle, and metabolic risk: evidence for a dose response. Obesity 200917 (Suppl 3) S27-S33. (doi:10.1038/oby.2009. 385)

15 Thyfault JP \& Booth FW. Lack of regular physical exercise or too much inactivity. Current Opinion in Clinical Nutrition and Metabolic Care 201114 374-378. (doi:10.1097/MCO.0b013e $3283468 \mathrm{e} 69$ )

16 Pedersen BK. The diseasome of physical inactivity - and the role of myokines in muscle - fat cross talk. Journal of Physiology 2009 $\mathbf{5 8 7} 5559$-5568. (doi:10.1113/jphysiol.2009.179515)

17 Alibegovic AC, Sonne MP, Hojbjerre L, Bork-Jensen J, Jacobsen S, Nilsson E, Faerch K, Hiscock N, Mortensen B, Friedrichsen M, Stallknecht B, Dela F \& Vaag A. Insulin resistance induced by physical inactivity is associated with multiple transcriptional changes in skeletal muscle in young men. American Journal of Physiology. Endocrinology and Metabolism 2010299 E752-E763. (doi:10.1152/ajpendo.00590.2009)

18 Sriwijitkamol A, Christ-Roberts C, Berria R, Eagan P, Pratipanawatr T, DeFronzo RA, Mandarino LJ \& Musi N. Reduced skeletal muscle inhibitor of $\kappa \mathrm{B} \beta$ content is associated with insulin resistance in subjects with type 2 diabetes: reversal by exercise training. Diabetes 200655 760-767. (doi:10.2337/diabetes.55. 03.06.db05-0677)

19 Herder C, Peltonen M, Koenig W, Sutfels K, Lindstrom J, Martin S, Ilanne-Parikka P, Eriksson JG, Aunola S, KeinanenKiukaanniemi S, Valle TT, Uusitupa M, Kolb H \& Tuomilehto J. Anti-inflammatory effect of lifestyle changes in the Finnish Diabetes Prevention Study. Diabetologia 200952 433-442. (doi:10.1007/s00125-008-1243-1)

20 Petersen AM \& Pedersen BK. The anti-inflammatory effect of exercise. Journal of Applied Physiology 200598 1154-1162. (doi:10.1152/japplphysiol.00164.2004)
21 Hamer M. The relative influences of fitness and fatness on inflammatory factors. Preventive Medicine 2007 44 3-11. (doi:10.1016/j.ypmed.2006.09.005)

22 Fleischman A, Shoelson SE, Bernier R \& Goldfine AB. Salsalate improves glycemia and inflammatory parameters in obese young adults. Diabetes Care 200831 289-294. (doi:10.2337/ dc07-1338)

23 Yuan M, Konstantopoulos N, Lee J, Hansen L, Li ZW, Karin M \& Shoelson SE. Reversal of obesity- and diet-induced insulin resistance with salicylates or targeted disruption of Ikk $\beta$. Science 2001293 1673-1677. (doi:10.1126/science.1061620)

24 Cai D, Frantz JD, Tawa NE Jr, Melendez PA, Oh BC, Lidov HG, Hasselgren PO, Frontera WR, Lee J, Glass DJ \& Shoelson SE. IKK $\beta / \mathrm{NF}-\kappa \mathrm{B}$ activation causes severe muscle wasting in mice. Cell 2004119 285-298. (doi:10.1016/j.cell.2004.09.027)

25 Friedrichsen M, Ribel-Madsen R, Wojtaszewski J, Grunnet L, Richter EA, Billestrup N, Ploug T, Vaag A \& Poulsen P. Dissociation between skeletal muscle inhibitor- $\kappa \mathrm{B}$ kinase/nuclear factor- $\kappa \mathrm{B}$ pathway activity and insulin sensitivity in nondiabetic twins. Journal of Clinical Endocrinology and Metabolism 201095 414-421. (doi:10.1210/jc.2009-1147)

26 Austin RL, Rune A, Bouzakri K, Zierath JR \& Krook A. siRNAmediated reduction of inhibitor of nuclear factor- $\mathrm{\kappa} B$ kinase prevents tumor necrosis factor- $\alpha$-induced insulin resistance in human skeletal muscle. Diabetes 200857 2066-2073. (doi:10.2337/db07-0763)

27 Sinha S, Perdomo G, Brown NF \& O'Doherty RM. Fatty acidinduced insulin resistance in L6 myotubes is prevented by inhibition of activation and nuclear localization of nuclear factor кB. Journal of Biological Chemistry 2004279 41294-41301. (doi:10.1074/jbc.M406514200)

28 Tantiwong P, Shanmugasundaram K, Monroy A, Ghosh S, Li M, DeFronzo RA, Cersosimo E, Sriwijitkamol A, Mohan S \& Musi N. $\mathrm{NF}-\mathrm{\kappa B}$ activity in muscle from obese and type 2 diabetic subjects under basal and exercise-stimulated conditions. American Journal of Physiology. Endocrinology and Metabolism 2010299 E794-E801. (doi:10.1152/ajpendo.00776.2009)

29 Marette A. Mediators of cytokine-induced insulin resistance in obesity and other inflammatory settings. Current Opinion in Clinical Nutrition and Metabolic Care 20025 377-383. (doi:10.1097/ 00075197-200207000-00005)

30 Pahl HL. Activators and target genes of Rel/NF- $\mathrm{BB}$ transcription factors. Oncogene 199918 6853-6866. (doi:10.1038/sj.onc. 1203239)

31 Ueda A, Okuda K, Ohno S, Shirai A, Igarashi T, Matsunaga K, Fukushima J, Kawamoto S, Ishigatsubo Y \& Okubo T. NF-кB and $\mathrm{Sp} 1$ regulate transcription of the human monocyte chemoattractant protein-1 gene. Journal of Immunology 1994153 2052-2063.

32 Kobara M, Sunagawa N, Abe M, Tanaka N, Toba H, Hayashi H, Keira N, Tatsumi T, Matsubara H \& Nakata T. Apoptotic myocytes generate monocyte chemoattractant protein-1 and mediate macrophage recruitment. Journal of Applied Physiology 2008 104 601-609. (doi:10.1152/japplphysiol.00254.2007)

33 Sell H, Dietze-Schroeder D, Kaiser U \& Eckel J. Monocyte chemotactic protein-1 is a potential player in the negative crosstalk between adipose tissue and skeletal muscle. Endocrinology 2006147 2458-2467. (doi:10.1210/en.2005-0969)

34 Kamei N, Tobe K, Suzuki R, Ohsugi M, Watanabe T, Kubota N, Ohtsuka-Kowatari N, Kumagai K, Sakamoto K, Kobayashi M, Yamauchi T, Ueki K, Oishi Y, Nishimura S, Manabe I, Hashimoto H, Ohnishi Y, Ogata H, Tokuyama K, Tsunoda M, Ide T, Murakami K, Nagai R \& Kadowaki T. Overexpression of monocyte chemoattractant protein- 1 in adipose tissues causes macrophage recruitment and insulin resistance. Journal of Biological Chemistry 2006281 26602-26614. (doi:10.1074/jbc. M601284200)

35 Hong EG, Ko HJ, Cho YR, Kim HJ, Ma Z, Yu TY, Friedline RH, Kurt-Jones E, Finberg R, Fischer MA, Granger EL, Norbury CC, Hauschka SD, Philbrick WM, Lee CG, Elias JA \& Kim JK. 
Interleukin-10 prevents diet-induced insulin resistance by attenuating macrophage and cytokine response in skeletal muscle. Diabetes 200958 2525-2535. (doi:10.2337/db08-1261)

36 Weisberg SP, McCann D, Desai M, Rosenbaum M, Leibel RL \& Ferrante AW Jr. Obesity is associated with macrophage accumulation in adipose tissue. Journal of Clinical Investigation 2003112 1796-1808.

37 Nguyen MT, Favelyukis S, Nguyen AK, Reichart D, Scott PA, Jenn A, Liu-Bryan R, Glass CK, Neels JG \& Olefsky JM. A subpopulation of macrophages infiltrates hypertrophic adipose tissue and is activated by free fatty acids via Toll-like receptors 2 and 4 and JNK-dependent pathways. Journal of Biological Chemistry 2007282 35279-35292. (doi:10.1074/jbc.M706762200)

38 Varma V, Yao-Borengasser A, Rasouli N, Nolen GT, Phanavanh B, Starks T, Gurley C, Simpson P, McGehee RE Jr, Kern PA \& Peterson CA. Muscle inflammatory response and insulin resistance: synergistic interaction between macrophages and fatty acids leads to impaired insulin action. American Journal of Physiology. Endocrinology and Metabolism 2009296 E1300-E1310. (doi:10. 1152/ajpendo.90885.2008)

39 Alibegovic AC, Hojbjerre L, Sonne MP, van Hall G, Stallknecht B, Dela $\mathrm{F} \&$ Vaag A. Impact of 9 days of bed rest on hepatic and peripheral insulin action, insulin secretion, and wholebody lipolysis in healthy young male offspring of patients with type 2 diabetes. Diabetes 200958 2749-2756. (doi:10.2337/ db09-0369)

40 Alibegovic AC, Hojbjerre L, Sonne MP, van Hall G, Alsted TJ, Kiens B, Stallknecht B, Dela F \& Vaag A. Increased rate of whole body lipolysis before and after 9 days of bed rest in healthy young men born with low birth weight. American Journal of Physiology. Endocrinology and Metabolism 2010298 E555-E564. (doi:10. 1152/ajpendo.00223.2009)

41 Sonne MP, Hojbjerre L, Alibegovic AC, Vaag A, Stallknecht B \& Dela F. Diminished insulin-mediated forearm blood flow and muscle glucose uptake in young men with low birth weight. Journal of Vascular Research 201047 139-147. (doi:10.1159/ 000235968)

42 Mootha VK, Lindgren CM, Eriksson KF, Subramanian A, Sihag S, Lehar J, Puigserver P, Carlsson E, Ridderstrale M, Laurila E, Houstis N, Daly MJ, Patterson N, Mesirov JP, Golub TR, Tamayo P, Spiegelman B, Lander ES, Hirschhorn JN, Altshuler D \& Groop LC. PGC- $1 \alpha$-responsive genes involved in oxidative phosphorylation are coordinately downregulated in human diabetes. Nature Genetics 200334 267-273. (doi:10.1038/ng1180)

43 Di Gregorio GB, Yao-Borengasser A, Rasouli N, Varma V, Lu T, Miles LM, Ranganathan G, Peterson CA, McGehee RE \& Kern PA. Expression of CD68 and macrophage chemoattractant protein-1 genes in human adipose and muscle tissues: association with cytokine expression, insulin resistance, and reduction by pioglitazone. Diabetes 200554 2305-2313. (doi:10.2337/diabetes.54. 8.2305)

44 Bruun JM, Helge JW, Richelsen B \& Stallknecht B. Diet and exercise reduce low-grade inflammation and macrophage infiltration in adipose tissue but not in skeletal muscle in severely obese subjects. American Journal of Physiology. Endocrinology and Metabolism 2006 290 E961-E967. (doi:10.1152/ajpendo.00506.2005)
45 Kunz-Schughart LA, Weber A, Rehli M, Gottfried E, Brockhoff G, Krause SW, Andreesen R \& Kreutz M. The "classical" macrophage marker CD68 is strongly expressed in primary human fibroblasts. Verhandlungen der Deutschen Gesellschaft für Pathologie $2003 \mathbf{8 7}$ 215-223.

46 Hermann TS, Rask-Madsen C, Ihlemann N, Dominguez H, Jensen CB, Storgaard H, Vaag AA, Kober L \& Torp-Pedersen C. Normal insulin-stimulated endothelial function and impaired insulin-stimulated muscle glucose uptake in young adults with low birth weight. Journal of Clinical Endocrinology and Metabolism 200388 1252-1257. (doi:10.1210/jc.2002-021550)

47 Huber J, Kiefer FW, Zeyda M, Ludvik B, Silberhumer GR, Prager G, Zlabinger GJ \& Stulnig TM. CC chemokine and CC chemokine receptor profiles in visceral and subcutaneous adipose tissue are altered in human obesity. Journal of Clinical Endocrinology and Metabolism 200893 3215-3221. (doi:10.1210/jc.2007-2630)

48 Lloyd PG, Prior BM, Yang HT \& Terjung RL. Angiogenic growth factor expression in rat skeletal muscle in response to exercise training. American Journal of Physiology. Heart and Circulatory Physiology 2003284 H1668-H1678.

49 Sell H \& Eckel J. Monocyte chemotactic protein-1 and its role in insulin resistance. Current Opinion in Lipidology $2007 \mathbf{1 8}$ 258-262. (doi:10.1097/MOL.0b013e3281338546)

50 Sourris KC, Lyons JG, de Courten MP, Dougherty SL, Henstridge DC, Cooper ME, Hage M, Dart A, Kingwell BA, Forbes JM \& de Courten B. JNK activity in subcutaneous adipose tissue but not $\mathrm{NF} \kappa \mathrm{B}$ activity in peripheral blood mononuclear cells is an independent determinant of insulin resistance in healthy individuals. Diabetes 200958 1259-1265. (doi:10.2337/ db08-1725)

51 Itani SI, Ruderman NB, Schmieder F \& Boden G. Lipid-induced insulin resistance in human muscle is associated with changes in diacylglycerol, protein kinase C, and IкB- $\alpha$. Diabetes 200251 2005-2011. (doi:10.2337/diabetes.51.7.2005)

52 Madonna R, Massaro M, Pandolfi A, Consoli A \& De Caterina R. The prominent role of $\mathrm{p} 38$ mitogen-activated protein kinase in insulin-mediated enhancement of VCAM-1 expression in endothelial cells. International Journal of Immunopathology and Pharmacology 200720 539-555.

53 Bertrand F, Philippe C, Antoine PJ, Baud L, Groyer A, Capeau J \& Cherqui G. Insulin activates nuclear factor $\kappa \mathrm{B}$ in mammalian cells through a Raf-1-mediated pathway. Journal of Biological Chemistry 1995270 24435-24441. (doi:10.1074/jbc.270.41. 24435)

54 Hojbjerre L, Sonne MP, Alibegovic AC, Nielsen NB, Dela F, Vaag A, Bruun JM \& Stallknecht B. Impact of physical inactivity on adipose tissue low-grade inflammation in first-degree relatives of type 2 diabetic patients. Diabetes Care 201134 2265-2272. (doi:10.2337/dc11-0631)

Received 8 June 2012

Revised version received 14 August 2012

Accepted 11 September 2012 